\title{
Open Letter to the World Health Organization and the UN Environment Programme
}

EPL initially received copies of this letter from colleagues who had been asked to join as signatories. The attached appears to be the final version, as posted online by various signatory organisations. It is reproduced intact, apart from adjusting a few typographical errors and the addition of footnotes (replacing internet links) to aid those who read the paper form of this journal. Ed.

Dear Dr Tedros Adhanom Ghebreyesus ${ }^{1}$ and Ms Inger Andersen, ${ }^{2}$

\section{COVID-19: Holistic, equitable solutions are required to improve human and planetary health and reduce zoonotic pandemic risks}

We, the undersigned individuals and organisations, commend the work the UN is doing to tackle the COVID-19 disease pandemic and its socio-economic consequences. The recently released UN Framework for the immediate socio-economic response to COVID-19 outlines the importance of shared responsibility and integration. However, more action is required, particularly on the environmental front. Urgent, far-reaching steps must be taken to reduce zoonotic pandemic risks and secure a better future not only for humans but also for nature, which underpins the health and wellbeing of all humanity. It is vital that any actions taken are appropriate and lead to socially just outcomes which contribute to - not detract from - the development of economically resilient livelihoods for those hundreds of millions of the world's most vulnerable who depend on wild resources for their survival.

COVID-19 is inflicting unprecedented social and economic costs on countries and communities, with the poor and vulnerable hardest hit. The virus's suspected links with a Chinese "wet market" has led to calls to ban wet markets and restrict or end the trade and consumption - for medicines or food - of wildlife. However, indiscriminate bans and restrictions risk being inequitable and ineffective. Wet markets, wildlife trade and consumption, and disease risks are all complex subjects. Wet markets (not all of which sell wild meat) provide invaluable food security; billions of people worldwide trade or consume wild meat and rely on wildlife use for livelihoods, while diseases are transmitted from livestock as well as wildlife.

There is an urgent need to tackle wildlife trade that is illegal, unsustainable or carries major risks to human health, biodiversity or animal welfare. Certain high-risk activities may rightfully necessitate targeted and/or time-bound bans, or severe restrictions (and rigorous enforcement), but it is vital that any such action is specific, appropriate, and equitable. If those targeted bans or severe restrictions are implemented, they should be accompanied by the meaningful provision of suitable alternative livelihoods for people affected. Furthermore, long-term success will require a holistic approach, including tackling issues like land conversion and industrial agriculture, which are major drivers of pandemic risk as well as biodiversity loss. Any actions must be undertaken in a targeted and socially just manner with due regard for human rights.

We recommend that the WHO and UNEP use their individual and collective expertise to

1. Work with the appropriate experts to identify areas and activities where wildlife trade and/or use poses high risks to zoonotic disease transmission, biodiversity conservation or welfare, and strengthen or develop tailored, locally appropriate strategies, with suitably improved regulation and enforcement, along the entire supply chain to reduce those risks; 
2. Initiate a coordinated response to the risks of pandemic emergence and biodiversity loss through the UN Environmental Management Group to raise intergovernmental awareness of the important role biodiversity plays in underpinning human health, the health risks associated with habitat destruction, and the value of sustainable use of biological resources (in line with Article 1 of the Convention on Biological Diversity (CBD) and guided by its 2004 Addis Ababa Principles);

3. Build partnerships across WHO, UNEP and other key stakeholders including IUCN, FAO and WTO, to explore how health considerations could be better aligned with trade regulations within the CITES framework, in clear recognition that biodiversity loss, unregulated trade and human health are inextricably linked;

4. Effectively engage with the CBD's ongoing process to develop the post-2020 Global Biodiversity Framework and associated Strategy for Resource Mobilization to ensure biodiversity is valued, conserved, restored and wisely used;

5. Support science- and human-rights-based, equitable approaches to conservation, in order to achieve the Sustainable Development Goals, and deliver comprehensive improvements to both human and planetary health.

The reasons for our recommendations are set out in Annex A, below the signatory list. Three hundred of the signatories (160 organisational signatories and 140 individual signatories) are shown below - more are on online and will continue to be collected:

\subsection{Organisational Signatories}

1. $\neq$ Khaodi // Hoas Conservancy Kunene South, Namibia

2. 1StopBorneo Wildlife, Brunei

3. African Wildlife Foundation (AWF), Kenya/International

4. Afrivet, South Africa

5. Ambrosius A. Community Forest Kavango West, Namibia

6. Anabeb Conservancy Kunene, Namibia

7. Asocaiman, Colombia

8. Association of Fish and Wildlife Agencies, USA

9. Association OKANI, Cameroon

10. Aube Nouvelle pour la Femme et le Développement (ANFD), Democratic Republic of the Congo

11. Balepye Community, South Africa

12. Botswana Wildlife Producers Association (BWPA), Botswana

13. Cameroon Youth Biodiversity Network, Cameroon

14. CAMPFIRE Association, Zimbabwe

15. CIC - International Council for Game and Wildlife Conservation, US/International

16. Climate Change Coalition Group, Zimbabwe

17. COMFAUNA (Comunidad de Manejo de Fauna Silvestre en Amazonía y América Latina), Latin America

18. Conservation Alliance International, Ghana

19. Conservation Alliance Sierra Leone, Sierra Leone

20. Conservation Frontlines Foundation, USA/South Africa

21. Conservation Outcomes, South Africa

22. Conservation Through Public Health, Uganda

23. Conservation Visions, Canada

24. Creative Conservation Solutions, Australia

25. Cuma Community Forest Kavango West, Namibia

26. Custodians of Professional Hunting and Conservation-SA, South Africa

27. Dallas Safari Club, USA

28. Earthmind, Switzerland

29. Eco Ranger Group, South Africa

30. EcoHealth Alliance, USA 
31. Ecolife Expeditions, South Africa

32. Ehirovipuka Conservancy - Kunene Region, Namibia

33. Endangered Wildlife Trust, South Africa

34. Environmental Conservation Trust of Uganda (ECOTRUST), Uganda

35. Environmental Foundation for Africa, Sierra Leone

36. Epupa Conservancy Kunene, Namibia

37. Erongo Regional Conservancy Association (North West), Namibia

38. Etanga Conservancy Kunene, Namibia

39. European Federation for Hunting and Conservation (FACE), Belgium

40. European Sustainable Use Group, UK

41. Farm Africa, UK/International

42. Fondation Camerounaise de la Terre Vivante (FCTV), Cameroon

43. Frankfurt Zoological Society, Germany/International

44. FundAmazonia, Peru

45. Fur Institute of Canada (FIC), Canada

46. Game Ranchers Forum, South Africa

47. Gcwatjinga Community Forest Kavango West, Namibia

48. Gender CC Women for Climate Justice, South Africa

49. Geo Wild Consult, South Africa

50. George Mukoya Conservancy Kavango East, Namibia

51. Giraffe Conservation Foundation, Namibia/International

52. Gonarezhou Conservation Trust, Zimbabwe

53. Greenhood Nepal, Nepal

54. Guide Outfitting Association of British Columbia, Canada

55. Hans Kanyinga Community Forest Kavango West, Namibia

56. Houston Safari Club, USA

57. Huab Conservancy (Kunene Region), Namibia

58. Integrated Rural Development and Nature Conservation (IRDNC), Namibia

59. Interdisciplinary Centre for Conservation Science and Oxford Martin Programme on the Illegal Wildlife Trade, UK

60. International Fur Federation, UK/International

61. Ipumbu Ya Tshilongo (North Central), Namibia

62. IUCN Group Sustainable Use and Management of Ecosystems (SUME), International

63. IUCN SSC Bear Specialist Group, International

64. IUCN SSC Caprinae Specialist Group, International

65. IUCN SSC-CEESP Sustainable Use and Livelihoods Specialist Group (SULi), International

66. IUCN Wildlife Health Specialist Group, International

67. Wildlife Producers Association of Zambia, Zambia

68. IWMC World Conservation Trust, Switzerland/International

69. Jamma International, UK/International

70. Japan Falconiformes Center, Japan

71. Kahenge Community Forest Kavango West, Namibia

72. Kapinga Kabwalye Community Forest Kavango West, Namibia

73. Kasungu Wildlife Conservation for Community Development, Malawi

74. Katope Community Forest Kavango West, Namibia

75. Keystone Foundation, India

76. Kunene Regional Communal Conservancy Association (KRCCA), Namibia

77. Kunene River Conservancy, Kunene, Namibia

78. Likwaterera Community Forest Kavango West, Namibia

79. Lion Landscapes, Kenya

80. Mahenye Community Committee, Zimbabwe

81. Malagasy Youth Biodiversity Network, Madagascar 
82. Marienfluss Conservancy Kunene, Namibia

83. Masoka CAMPFIRE Association, Zimbabwe

84. Masoka Community, Zimbabwe

85. Maurisi Nekaro Conservancy Kavango East, Namibia

86. Mbeyo Community Forest Kavango West, Namibia

87. Mbire Rural District Council, Zimbabwe

88. Muduva Nyangana Conservancy (Kavango East), Namibia

89. Namibia Nature Foundation (NNF), Namibia

90. Namibian Chamber of Environment, Namibia

91. Namibian Association of CBNRM Support Organisations (NACSO), Namibia

92. Ncamacoro Community Forest Kavango West, Namibia

93. Ncaute Community Forest Kavango West, Namibia

94. Ngamiland Council of Non-Governmental Organisations (NCONGO), Botswana

95. Norwegian Pet Trade Association, Norway

96. Okandundumba Conservancy Kunene, Namibia

97. Okanguati Conservancy Kunene, Namibia

98. Okatjandjakozomenje Conservancy Kunene, Namibia

99. Okondjombo Conservancy Kunene, Namibia

100. Okongoro Conservancy Kunene, Namibia

101. Ombazu Conservancy Kunene, Namibia

102. Ombombo masitu Conservancy Kunene, Namibia

103. Ombujokanguindi Conservancy Kunene, Namibia

104. Ongongo Conservancy Kunene, Namibia

105. Ornamental Fish International (OFI), The Netherlands

106. Orupembe Conservancy Kunene, Namibia

107. Orupupa Conservancy Kunene, Namibia

108. Otjambangu Conservancy Kunene, Namibia

109. Otji West Conservancy Kunene, Namibia

110. Otjikondavirongo Conservancy Kunene, Namibia

111. Otjikongo Conservancy Kunene, Namibia

112. Otjimboyo Conservancy (Erongo Region), Namibia

113. Otjindjerese Conservancy Kunene, Namibia

114. Otjitanda Conservancy Kunene, Namibia

115. Otjombande Conservancy Kunene, Namibia

116. Otuzemba Conservancy Kunene, Namibia

117. Ozondundu Conservancy Kunene, Namibia

118. People for Pangolins, International

119. Puros Conservancy Kunene, Namibia

120. Resource Africa South Africa, South Africa

121. Resource Africa UK, UK

122. Ruaha Carnivore Project, Tanzania

123. Safari Club International Foundation, USA

124. Sanitatis Conservancy Kunene, Namibia

125. Save the Rhino Trust Namibia, Namibia

126. Sesfontein Conservancy Kunene, Namibia

127. Sheya Shuushona Conservancy (North Central Regions), Namibia

128. Sidinda Community Committee, Zimbabwe

129. Sikunga Conservancy (Zambezi Region), Namibia

130. Sorris Sorris Conservancy (Southern Kunene), Namibia

131. South African Hunters and Game Conservation Association, South Africa

132. South African Wingshooters Association, South Africa

133. South African Youth Biodiversity Network, South Africa 
134. South Asia Reptile Conservation Alliance, International

135. Southern African Wildlife Management Association, South Africa

136. Stellenbosch University, South Africa

137. Support for Women in Agriculture and Environment (SWAGEN), Uganda

138. Sustainable Users Network (SUN), UK

139. Tanzania Natural Resources Forum (TNRF), Tanzania

140. The Conservation Coalition Botswana (TCCB), Botswana

141. The Development Institute, Ghana

142. The Game Rangers Association of Africa (GRAA), South Africa

143. The Wildlife Society, USA

144. Torra Conservancy Kunene South, Namibia

145. Tsiseb Conservancy (Erongo Region), Namibia

146. Uibasen Conservancy (Southern Kunene), Namibia

147. Uukwaludhi Conservancy (North Central Regions), Namibia

148. Wild Africa Conservation, Niger

149. Wild Sheep Foundation, USA

150. Wildlife \& Environment Society of Southern Africa, South Africa

151. Wildlife Environmental Society of Malawi, Malawi

152. Wildlife Producers Association, South Africa

153. Wildlife Producers Association of Zambia, Zambia

154. Wildlife Ranching South Africa, South Africa

155. WILDOCEANS, South Africa

156. Women Environmental Programme (WEP), Nigeria

157. Women in Conservation (Kunene Region), Namibia

158. Working Dogs for Conservation, USA

159. Zambia CBNRM Association, Zambia

160. Zambia National Community Resources Board Association, Zambia

\subsection{Individual Signatories}

1. Vanessa Adams, University of Tasmania, Australia

2. Steve Alexander, Conservation and Wildlife Fund, Hwange National Park, Zimbabwe

3. Benjamin Allen, University of Southern Queensland, Australia

4. Shaista Andleeb, Wuhan University of Technology, China

5. Peter Apps, Botswana Predator Conservation, Botswana

6. Michael Archer, University of New South Wales (UNSW), Australia

7. Nathan J. Bennett, IUCN CEESP/SSC SULi Central Asia, Canada

8. Duan Biggs, Griffith University, Australia

9. Bernd Blossey, Cornell University, USA

10. Hollie Booth, ICCS, University of Oxford, UK

11. Adri Kitshoff Botha, Wildlife Ranching South Africa, South Africa

12. Peadar Brehony, Department of Geography, University of Cambridge, UK

13. Peter Bridgewater, Copernicus Institute of Sustainable Development, Netherlands

14. Stephanie Brittain, Interdisciplinary Centre for Conservation Science, UK

15. Christopher Brown, Namibian Chamber of Environment, Namibia

16. Francois du Toit, Project Africa, Sweden

17. Donna-Maree Cawthorn, University of Mpumalanga, South Africa

18. Dan Challender, University of Oxford, UK

19. Philippe Chardonnet, IUCN SSC Antelope Specialist Group, France

20. Brian Child, University of Florida, USA

21. Simon Clulow, Macquarie University, Australia 
22. John Clulow, University of Newcastle, Australia

23. Peter Coals GR, WildCRU, University of Oxford, UK

24. Bernard Coetzee, Global Change Institute, University of the Witwatersrand, South Africa

25. Calvin Cottar, Cottars Wildlife Conservation Trust, Kenya

26. Alayne Cotterill, WildCRU, University of Oxford, UK

27. Marianne Courouble, International Biodiversity Consulting, France

28. Jeremy Cusack, Universidad Mayor, Santiago, Chile

29. Harriet Davies-Mostert, Endangered Wildlife Trust, South Africa

30. Emiel de Lange, School of Geosciences, University of Edinburgh, UK

31. Amy Dickman, WildCRU, University of Oxford, UK

32. Egil Droge, WildCRU, University of Oxford, UK

33. Morné du Plessis, WWF South Africa, South Africa

34. Byron du Preez, Jesus College, University of Oxford, UK

35. Holly Dublin, IUCN SULi, Kenya

36. Sarah Durant, Institute of Zoology, Zoological Society of London, UK

37. John E. Fa, CIFOR, UK

38. Christo Fabricius, Nelson Mandela University, South Africa and member of IUCN Commission on Environmental, Economic and Social Policy (CEESP), South Africa

39. Ruth Feber, WildCRU, University of Oxford, UK

40. Marco Festa-Bianchet, Canada

41. Svein A. Fosså, Norwegian Pet Trade Association (NZB), Norway

42. Edson Gandiwa, Chinhoyi University of Technology, Zimbabwe

43. Tuqa Jirmo, Lewa Wildlife Conservancy, Kenya

44. Jenny A. Glikman, San Diego Zoo, USA

45. Paul Goriup, NatureBureau, UK

46. Andrea Griffin, University of Newcastle, Australia

47. Sunetra Gupta, University of Oxford, UK

48. John Hanks, Independent Environmental Consultant, South Africa

49. Darragh Hare, Department of Natural Resources, Cornell University, USA

50. Alasdair Harris, Blue Ventures, UK

51. Adam Hart, University of Gloucestershire, UK

52. Matt Hayward, University of Newcastle, Australia

53. Juan Herrero, Universidad de Zaragoza, Spain

54. Rachel Hoffmann, University of Cambridge, UK

55. Hiromasa Igota, Rakuno Gakuen University, Japan

56. Wei JI, IUCN SULi, China

57. Paul Johnson, University of Oxford, UK

58. Khalil Karimov, IUCN CEESP/SSC SULi, Tajikistan

59. Graham I.H. Kerley, Nelson Mandela University, South Africa

60. Ambika Khatiwada, National Trust for Nature Conservation, Nepal

61. Rebecca Klein, Cheetah Conservation Botswana, Botswana

62. Emmanuel Koro, Environmental journalist, South Africa

63. Paige Lee, IUCN SSC Pangolin Specialist Group, UK

64. Gabriela Lichtenstein, National Research Council (CONICET), Argentina

65. Mohsin Lee Likoniwalla, Animal Care Centre, Nairobi, Kenya

66. Xin Liu, China Northeast Forestry University, China

67. Ewan Macdonald, Saïd Business School, University of Oxford, UK

68. Ian Macdonald, University of Cape Town, South Africa

69. Duncan MacFadyen, Oppenheimer Generations, South Africa

70. Masego Madzawmuse, IUCN CEESP and Southern Africa Trust, South Africa

71. Prince Dipati Maenetja, Balepye Community, South Africa

72. Reuben Malema, BE Products (Pty) Ltd, South Africa 
73. Stefan Michel, IUCN Sustainable Use and Livelihoods Specialist Group (SULi), Germany

74. E.J. Milner-Gulland, University of Oxford, UK

75. Nick Mitchell, Zoological Society of London, UK

76. Axel Moehrenschlager, Centre for Conservation Research, Calgary Zoological Society, Canada

77. Vik Mohan, Blue Ventures, UK

78. Tom Moorhouse, University of Oxford, UK

79. Paola Mosig Reidl, CONABIO, Mexico

80. Victor K. Muposhi, Chinhoyi University of Technology, Zimbabwe

81. Aibat Muzbay, Kazakhstan Wildlife Foundation, Kazakhstan

82. Naveen Namboothri, Dakshin Foundation, India

83. Eric Djomo Nana, Agricultural Research Institute for Development (IRAD), Cameroon

84. Robert Nasi, CIFOR, Indonesia

85. Daniel Natusch, EPIC Biodiversity, Australia and France

86. Helen Newing, ICCS, University of Oxford, UK

87. Germain Ngandjui, Cameroon Canada Biodiversity Conservation Association, Cameroon

88. Andrew Norton, International Institute for Environment and Development (IIED), UK

89. Christine Nyangweso, Kenya Wildlife Service, Kenya

90. Mike O'Brien, Fur Institute of Canada, Canada

91. Alegria Olmedo, University of Oxford, UK

92. Meera Anna Oommen, Dakshin Foundation, India

93. Josep Oriol, Okavango Capital, Kenya

94. Norman Owen-Smith, University of the Witwatersrand, South Africa

95. Elisa Panjang, University of Cardiff, UK

96. Despina Symons Pirovolidou, European Bureau for Conservation and Development (EBCD), Belgium

97. Gail Potgieter, Felines Communication and Conservation Consultants, Namibia

98. Madhu Ramnath, NTFP Exchange Programme India, India

99. David Roberts, Durrell Institute of Conservation and Ecology, UK

100. Tim Roberts, University of Newcastle, UK

101. Dilys Roe, IUCN Sustainable Use and Livelihoods Specialist Group and International Institute for Environment and Development, UK

102. Ramón Peréz Gil Salcido, FAUNUM, Mexico

103. Lilian Sales, University of Campinas (UNICAMP), Brazil

104. Chris Sandbrook, University of Cambridge, UK

105. Ed Sayer, North Luangwa Conservation Programme, Zambia

106. Charlotte Searle, WildCRU, University of Oxford, UK

107. Catherine E. Semcer, Property and Environment Research Center, USA

108. Orynbassar Shaimukhanbetov, Kazakhstan Wildlife Foundation, Kazakhstan

109. Kartik Shanker, Indian Institute of Science and Dakshin Foundation, India

110. Pasang Dolma Sherpa, Center for Indigenous Peoples' Research and Development (CIPRED), Nepal

111. Janusz Sielicki, Falcon Society, Poland

112. Keith Somerville, Durrell Institute of Conservation and Ecology, UK

113. Anna Spenceley, IUCN WCPA Tourism and Protected Areas Specialist Group, UK

114. Oliver Springate-Baginski, School of Development Studies, University of East Anglia, UK

115. Aarthi Sridhar, Dakshin Foundation, India

116. Don Stacey, Masebe Ranch, Zambia

117. Mark Stanley-Price, WildCRU, University of Oxford, UK

118. Paolo Strampelli, WildCRU, University of Oxford, UK

119. Cedric Thibaut Kamogne Tagne, Fondation Camerounaise de la Terre Vivante (FCTV), Cameroon

120. Simo Talla, University of Yaoundé, Cameroon

121. Francis Nchembi Tarla, Central African Bushmeat Action Group (CABAG), Cameroon

122. Taye Teferi, IUCN Sustainable Use and Livelihoods Specialist Group (SULi), International

123. Scott Trageser, The Biodiversity Group, USA 
124. Piotr Tryjanowski, Poznan University of Life Sciences, Poland

125. Michael 't Sas-Rolfes, University of Oxford, UK

126. Dino Tumazos, COLCOM, Zimbabwe

127. Andrew van Heerden, The Conservation Imperative, South Africa

128. Nathalie van Vliet, Center for International Forestry Research (CIFOR), France

129. Diogo Veríssimo, ICCS, University of Oxford, UK

130. Karl Vernes, University of New England, Australia

131. Frederick J. Verreynne, Botswana Wildlife Producers Association, Botswana

132. Jako Volschenk, University of Stellenbosch Business School, South Africa

133. Francis Vorhies, African Leadership University, Rwanda

134. Gretchen Walters, Institute of Geography and Sustainability, University of Lausanne, Switzerland

135. Dominic Whitmee, The Ornamental Aquatic Trade Association (OATA), UK

136. Matthew Wijers, WildCRU, University of Oxford, UK

137. Jane Wiltshire, Fellow of the African Wildlife Economics Institute of the University of Stellenbosch, South Africa

138. James Wood, University of Cambridge, UK

139. Shibao Wu, South China Normal University, China

140. Mary Wykstra, Action for Cheetahs in Kenya, Kenya

\section{Annex A}

\subsection{Pandemic Risk Reduction Measures Must Not Exacerbate Poverty and Inequality}

Since its inception, the WHO has defined health as "a state of complete physical, mental and social well-being". 3 Health is inextricably linked to nature, which underpins our physical and mental wellbeing, and to poverty. The COVID-19 pandemic is far more than an immediate health crisis: it is also unleashing unprecedented economic ${ }^{4}$ and social chaos. It is currently estimated to be costing the global economy US $\$ 1$ trillion in 2020 alone, ${ }^{5}$ with the International Labour Organization predicting cutbacks equivalent to nearly 200 million full-time workers in just three months. ${ }^{6}$ Marginalised and vulnerable communities are likely to bear the brunt of these impacts, with UNDP warning that nearly half the jobs in Africa could be lost. ${ }^{8}$ Worldwide, nearly half a billion more people could be pushed into poverty, with the crisis disproportionately affecting women, leading to wide-ranging social impacts including human rights abuses. ${ }^{9}$ Over half the global population could be living in poverty after the pandemic, with particularly severe impacts in sub-Saharan Africa, North Africa and the Middle East.

As the COVID-19 crisis will deepen poverty and damage health, potentially for generations, it is unconscionable that measures aimed at preventing future pandemics should compound this by further disadvantaging the world's most vulnerable people, for instance through indiscriminate bans on food markets, or unnecessary restrictions on wildlife trade. Millions of poorer households, especially in rural areas, are particularly dependent upon using wild resources for livelihoods and as insurance against economic shocks, whilst in urban areas millions more rely upon affordable produce from wet markets for food security. ${ }^{10}$ Over a billion people worldwide, including indigenous peoples and local communities (IPLCs), rely on using and trading wildlife, by selling and consuming wild meat, fish, insects and plants, extracting timber and forest products, and many other activities. Many of these activities are legal, regulated and essential for livelihoods, and pose no significant threat to human health or biodiversity - indeed, when well regulated, wildlife trade can actually be beneficial for conservation. Indiscriminate restrictions risk unnecessarily exacerbating poverty and inequality without commensurate benefits.

\subsection{Wildlife Trade Must be Addressed in a Targeted, Tailored and Effective Way}

Wildlife trade, particularly in "wet markets", has become a central part of the discourse around COVID19 , and it has been suggested that banning wet markets, and banning or severely restricting wildlife trade and 
consumption, could reduce future pandemic risks. However, these are complex topics. Wet markets underpin the informal food systems on which millions of urban and rural people depend. They sell a range of fresh produce: fruit and vegetables, fish, livestock and, sometimes, wildlife. Wildlife trade and consumption encompasses a wide variety of species, both common and rare, and a vast array of uses including food, medicines, clothing, textiles, pets and ornaments. Its drivers and dynamics are complex and varied. Even if wildlife trade bans were just focused on food, it is important to note that zoonotic diseases also emerge from domestic species. Focusing on Asian markets also ignores the fact that billions of people, in both the Global North and South, consume wild meat from both common and "exotic" species. Furthermore, current proposals to ban all wildlife trade undermine both the spirit and efficacy of the Convention on International Trade in Endangered Species (CITES), which seeks to regulate trade for the benefit of species conservation and enable trade that is legal, sustainable, and supportive of conservation and human livelihoods. It would be more productive for the WHO, UNEP and other stakeholders to work with CITES to align human health considerations with the objectives of the Convention.

Suggestions that pandemics could be avoided by imposing a global ban on wildlife markets or indiscriminately restricting wildlife trade are simplistic and risk enormous unintended consequences, including criminalising and further impoverishing countless people. Externally-imposed bans can drive trade underground and enmesh it with other organised criminal activity, as occurred after the 2013-2016 Ebola outbreak. In that situation, regulations would become harder to enforce, with lower standards of hygiene and animal welfare, and higher likelihood of zoonotic disease outbreak. Furthermore, demand may remain if a legal supply is suddenly removed (especially if captive breeding is also banned, as some recommend), risking a rise in black market prices and increased incentives for poaching. This could accelerate the exploitation and extinction of species in the wild. The risks associated with indiscriminate trade restrictions highlight the need for targeted regulation and enforcement tailored to each specific situation, at the appropriate level. This will increase the likelihood of achieving desired outcomes for conservation, health and animal welfare, while reducing unintended consequences for people and wildlife.

\subsection{Holistic, Far-sighted Solutions are Required to Improve Human and Planetary Health}

This pandemic is a wake-up call with regard to our destructive relationship with nature. Wildlife trade is only one of many factors that must be addressed to reduce zoonotic disease outbreaks, secure biodiversity and improve human and planetary health. Habitat destruction and industrial agriculture play key roles in increasing zoonotic disease transmission from wildlife to humans, as people and their livestock come into ever closer proximity to wild species and pathogens. ${ }^{11}$ In addition to catastrophic ecological impacts, the destruction of nature, in conjunction with climate change, has long-term, devastating impacts on human physical and mental health. ${ }^{12}$ The role of domestic species in zoonotic outbreaks such as pandemic influenza must also be considered. Disease risks and welfare in farmed-animal supply chains should also be examined robustly, with risk reduction strategies targeted at the highest-risk species, whether domestic or wild. More widely, holistic approaches should be developed which look beyond pandemics, such as limiting antibiotic use in livestock to reduce risks of antibiotic resistance, which poses a major danger to human health. Business as usual cannot continue, and the WHO and UNEP are well positioned to encourage governments and other agencies to fully recognise the interconnected nature of planetary and human health. There is a need for a "One Health" coordinated approach both across the $\mathrm{UN}$, including the WHO, UNEP, UNDP and the FAO, and beyond with other relevant organisations including the World Organisation for Animal Health (OIE) and the World Trade Organization (WTO). This synergistic approach would help develop and deliver a better, more equitable future for humans and the ecosystems which underpin our society.

\subsection{Summary}

The response to COVID-19 has demonstrated that transformational action is possible if governments and citizens are convinced that the risks of inaction outweigh the costs. We urgently need similar transformational action to safeguard nature, delivering critical long-term benefits for both human and planetary health as part of our response to COVID-19. Robust, long-lasting measures must be taken to safeguard and adequately fund 
the protection of nature and invest in science- and rights-based conservation and restoration. Devastating as the COVID-19 pandemic is, recovery from this crisis provides an unparalleled moment to create a better and more sustainable future. We must change our relationship with nature and develop appropriate strategies to equitably and sustainably manage the biodiversity upon which so many livelihoods depend. Changes must be inclusive, well-considered and socially and economically just, and every care must be taken not to exacerbate poverty and amplify existing inequalities.

The sustainable and inclusive management of nature is recognised throughout the UN as a key element to achieving poverty reduction objectives and meeting the Sustainable Development Goals. Indiscriminate restrictions on wildlife trade will devastate livelihoods, cause major harm to human health and wellbeing and undermine human rights, without significant benefits for biodiversity or health. Strategic, equitable, coordinated and holistic approaches are more likely to reduce pandemic risks, achieve a better future for both human and planetary health, and should be a core component of future WHO/UNEP recommendations.

CC: Achim Steiner, Administrator UNDP

Elizabeth M. Mrema, Executive Secretary, Convention on Biological Diversity, CBD

Qu Dongyu, Director General, Food and Agriculture Organization, FAO

Ivonne Higuero, CITES Secretary General

Grethel Aguilar, Acting Director General, IUCN

Michelle Bachelet, UN Human Rights Commissioner

David Boyd, UN Special Rapporteur on Human Rights and Environment

David Nabarro, Special Envoy to WHO DG on COVID-19

\section{Additional References}

Humane Society International. 2020. "A Ban on Wildlife Trade, Markets, Transport and Consumption Would Significantly Reduce the Risk of Another Pandemic". An Open Letter to Governments, 7 April. Available at https://www.hsi.org/wp-content/uploads/2020/04/ COVID19-Open-Cover-Letter-for-White-Paper.pdf.

International Panel of Experts on Sustainable Food Systems. 2020. "COVID-19 and the crisis in food systems: Symptoms, causes, and potential solutions". Communiqué by IPES-FOOD, April 2020. Available at http://www.ipes-food.org/_img/upload/files/COVID-19_ CommuniqueEN.pdf.

Jones, M. 2020. "Live Wild Animal Markets, Human and Animal Health, and Biodiversity Protection”. Joint open letter to the heads of the WHO, UNEP and OIE. Available at https://www.bornfree.org.uk/storage/media/content/files/WildlifeMarketClosureLetter_Feb20_ FINALV3_1.pdf.

Patz, J., Corvalan, C. et al. 2012. Our Planet, Our Health, Our Future. Human health and the Rio Conventions: biological diversity, climate change and desertification. Geneva: WHO. Available at https://www.who.int/globalchange/publications/reports/health rioconventions.pdf.

Rowling, M. 2020. "Nearly Half of All Jobs in Africa Could Be Lost to COVID-19, Warns UN Development Programme". Global Citizen, 6 April. Available at https://www.globalcitizen.org/en/content/covid-19-could-cost-millions-of-jobs-in-africa/.

Schreiber, M. 2020. "A Better Way to Stop Coronaviruses". TNR, 29 January. Available at https://newrepublic.com/article/156359/betterway-stop-coronaviruses.

Taub, A. 2020. "A New Covid-19 Crisis: Domestic Abuse Rises Worldwide". The New York Times, 6 April. Available at https://www.nytimes. com/2020/04/06/world/coronavirus-domestic-violence.html.

UN Department of Global Communications. 2020. "UN working to fight COVID-19 and achieve Global Goals". Available at http://www.un.org/en/un-coronavirus-communications-team/un-working-fight-covid-19-and-achieve-global-goals.

United Nations Sustainable Development Group. 2020. "Shared Responsibility, Global Solidarity: Responding to the socio-economic impacts of COVID-19”. Available at https://unsdg.un.org/sites/default/files/2020-03/SG-Report-Socio-Economic-Impact-of-Covid19.pdf.

Wenham, C., Smith, J. and Morgan, R. 2020. “COVID-19: the gendered impacts of the outbreak”. The Lancet 395(10227): 846-848. Available at https://www.thelancet.com/journals/lancet/article/PIIS0140-6736(20)30526-2/fulltext.

World Health Organization. 2017. "One Health”. Available at https://www.who.int/news-room/q-a-detail/one-health. 


\section{Endnotes}

${ }^{1}$ [Director-General, World Health Organization. Ed.]

${ }^{2}$ [Executive Director of the United Nations Environment Programme. Ed.]

${ }^{3}$ World Health Organization. "Frequently asked questions: What is the WHO definition of health?" Online at https://www.who.int/about/ who-we-are/frequently-asked-questions.

${ }^{4}$ World Economic Forum website. "This is how much the coronavirus will cost the world's economy, according to the UN". Online at https://www.weforum.org/agenda/2020/03/coronavirus-covid-19-cost-economy-2020-un-trade-economics-pandemic/.

${ }^{5}$ Ibid.

${ }^{6}$ UN News. 8 April 2020. "COVID-19: impact could cause equivalent of 195 million job losses, says ILO chief". Online at https://news.un.org/en/story/2020/04/1061322.

${ }^{7}$ Sands, P. 2020. "COVID-19 Threatens the Poor and Marginalized More than Anyone". OCHA Services reliefweb, 7 March. Online at https://reliefweb.int/report/world/covid-19-threatens-poor-and-marginalized-more-anyone.

${ }^{8}$ Smith, C. 2020. "Nearly half of jobs in Africa could be lost due to coronavirus, UN warns". Fin24, 30 March. Online at https://www.news24.com/fin24/Economy/Africa/nearly-half-of-jobs-in-africa-could-be-lost-due-to-coronavirus-un-warns20200330.

${ }^{9}$ Oxfam International. 2020. "Dignity not destitution: An 'Economic Rescue Plan For All' to tackle the Coronavirus crisis and rebuild a more equal world". Online at https://www.oxfam.org/en/research/dignity-not-destitution.

${ }^{10}$ TEEB. 2010. The Economics of Ecosystems and Biodiversity: Mainstreaming the Economics of Nature: A synthesis of the approach, conclusions and recommendations of TEEB. Nairobi: UNEP. Online at http://doc.teebweb.org/wp-content/uploads/Study\%20and\%20 Reports/Reports/Synthesis\%20report/TEEB\%20Synthesis\%20Report\%202010.pdf.

${ }^{11}$ Vidal, J. 2020. “'Tip of the iceberg': is our destruction of nature responsible for Covid-19?” The Guardian, 18 March. Online at https://www.theguardian.com/environment/2020/mar/18/tip-of-the-iceberg-is-our-destruction-of-nature-responsible-for-covid-19aoe.

${ }^{12}$ World Health Organization website. "Climate Change and Human Health: Biodiversity”. Online at https://www.who.int/globalchange/ ecosystems/biodiversity/en/. 